Jurnal Pena Sains Vol. 5, No. 1, April 2018

\title{
CALCIUM OXIDE CHARACTERISTICS PREPARED FROM AMBUNTEN'S CALCINED LIMESTONE
}

\author{
Fatimatul Munawaroh $^{1}$, Laila Khamsatul Muharrami², Triwikantoro ${ }^{3}$ dan Zaenal Arifin ${ }^{4}$ \\ 1,2 Natural Science Education Study Program, Faculty of Education, University of Trunojoyo Madura \\ Bangkalan 69162, Indonesia \\ ${ }^{1}$ fatim@trunojoyo.ac.id, ${ }^{2}$ laila@trunojoyo.ac.id
}

\author{
${ }^{3,4}$ Physiscs Department, Faculty of Natural Science, Sepuluh Nopember Institute of Technology \\ Surabaya 60111, Indonesia \\ 3triwi@physics.its.ac.id, ${ }^{4}$ zaenalw18@gmail.com
}

\begin{abstract}
Calcium oxide $(\mathrm{CaO})$ and calcium carbonate $(\mathrm{CaCO} 3)$ are widely used in industry. $\mathrm{CaO}$ and $\mathrm{CaCO} 3$ can be synthesized or derived from limestone. The purpose of this study to determine the characteristics of $\mathrm{CaO}$ calcined limestone from Ambunten Sumenep. Lime in calcined at $850^{\circ} \mathrm{C}$ for 6 hours. Characterization of X-ray fluorescence (XRF) was conducted to determine the chemical composition of limestone, X-ray diffraction test (XRD) to find the lime crystalline phase and FTIR test to determine the absorption of wave number. XRF test results showed that the limestone chemical composition consisted of $\mathrm{Ca}$ of $95.37 \%$ as the dominant element, $\mathrm{Mg}$ of $4.1 \%, \mathrm{Fe} 0.17 \%$ and $\mathrm{Y}$ by $0.39 \%$. The XRD test results showed that the limestone crystal phase is ankerite $(\mathrm{Ca}[\mathrm{Fe}$, $\mathrm{Mg}][\mathrm{CO} 3] 2)$ and after the calcined phase calcination is vaterite $(\mathrm{Ca}[\mathrm{OH}] 2)$, calcite $(\mathrm{CaO})$ and calcite $(\mathrm{CaCO} 3)$. While the FTIR test results show that the $\mathrm{CaO}$ spectra are seen at 3741.24, 1417.12 and $874.14 \mathrm{~cm}^{-1}$.
\end{abstract}

Keywords: calcination, calcium oxide, $\mathrm{CaO}$, limestone 


\section{Introduction}

Limestone-based carbonate in Indonesia is abundant. Deposition of mineral resources is spread from the island of Sumatra, Java, Nusa Tenggara, Sulawesi, Irian Jaya, Madura and other islands (Aziz, 2010). Madura also has high limestone potential. Its use is still limited to lime, lime pairs, building materials and raw materials in the cement industry, so it has a low economic value (Khaira, 2011).

Efforts to increase the added value of limestone have been done, among others, to make the Ground Calcium Carbonate (GCC) or Precipitated Calcium Carbonate (PCC). In addition, limestone can also be processed into calcium oxide $(\mathrm{CaO})$ by a process of calcination. $\mathrm{CaO}$ is widely used as a catalyst in biodiesel production (Mohadi et al., 2013, Suprato et al., 2016, Widayat et al., 2017, Itudo et al., 2017).

Many researchers have synthesized $\mathrm{CaO}$ from limestone ie Suprapto et al (2016) by thermal decomposition method in a furnace at $800^{\circ} \mathrm{C}$ for 6 hours and coprecipitation. Widayat et al (2017) with calcination at $900{ }^{\circ} \mathrm{C}$ for 1.5 hours. Itudo et al (2017) with a process of calcining temperature variations of $650,700,750$, $800,850,900,950,1000,1050$ and $1200^{\circ} \mathrm{C}$ for $140 \mathrm{~min}$. The main purpose of this research is to investigate the characteristics of $\mathrm{CaO}$ with calcination process using natural limestone from Ambunten Sumenep.

\section{Research Methods}

Samples of limestone were taken from the village of Ambunten Tengah Ambunten subdistrict, Sumenep Madura Island. The sample was crushed with mortar then sieved using a mesh size of
18 mesh and 35 mesh. The chemical composition of limestone was tested using X-Ray Flourescence (XRF) PANanaytical Minipal 4 Sulfur and limestone crystalline phase characterized using X-Ray Diffraction (XRD) X-Pert MPD with $\mathrm{Cu}$ $\mathrm{K} \alpha$ radiation $(\lambda=1,5406 \AA$ ) and scanned from $10^{\circ}$ to $60^{\circ}$. $\mathrm{CaO}$ was obtained by calcining limestone at a temperature of $850^{\circ} \mathrm{C}$ for 6 hours. Furthermore, calcination chalk was characterized by $\mathrm{XRD}$ to determine the $\mathrm{CaO}$ phase formed and the functional group $\mathrm{CaO}$ analysis was analyzed using infrared spectroscopy equipped with Fourier Transform (FTIR). The crystal size of $\mathrm{CaO}$ was analyzed using Scherrer equation:

$$
D=\frac{0.9 \lambda}{B \cos \theta}
$$

where $\lambda$ is $X$-Ray wavelength (nm)and B is the peak width of the diffraction peak profile at half maximum height (rad).

\section{Results and Discussion}

Table 1 is an XRF test result that describes the limestone chemical composition of the village of Ambunten Tengah, Sumenep. It is seen that the highest constituent element is $\mathrm{Ca} 95.37$ wt\% with $\mathrm{CaO} 93.67$ wt\%, and there are $\mathrm{Mg}$ impurity element at $4.1 \mathrm{wt} \%$, Fe equal to $0.17 \mathrm{wt} \%$ and $\mathrm{Y}$ of $0.39 \%$. Ca element content of $95.37 \mathrm{wt} \%$ higher than the limestone obtained by Arifin et al (2017) from the mining in Tuban, ie Ca 92.40 wt $\%$. $\mathrm{CaO}$ content of $93.67 \mathrm{wt} \%$ higher than the limestone obtained by Sari et al (2013) from the mining in Aceh Tamiang region, ie $\mathrm{CaO} 61.20 \mathrm{wt} \%$. 
Table 1. The chemical composition of limestone Ambunten Sumenep

\begin{tabular}{cccc}
\hline Element & wt $(\%)$ & Oxide & wt $(\%)$ \\
\hline $\mathrm{Ca}$ & 95.37 & $\mathrm{CaO}$ & 93.67 \\
$\mathrm{Mg}$ & 4.1 & $\mathrm{MgO}$ & 5.7 \\
$\mathrm{Fe}$ & 0.17 & $\mathrm{Fe}_{2} \mathrm{O}_{3}$ & 0.15 \\
$\mathrm{Y}$ & 0.39 & $\mathrm{Y}_{2} \mathrm{O}_{3}$ & 0.48 \\
\hline
\end{tabular}

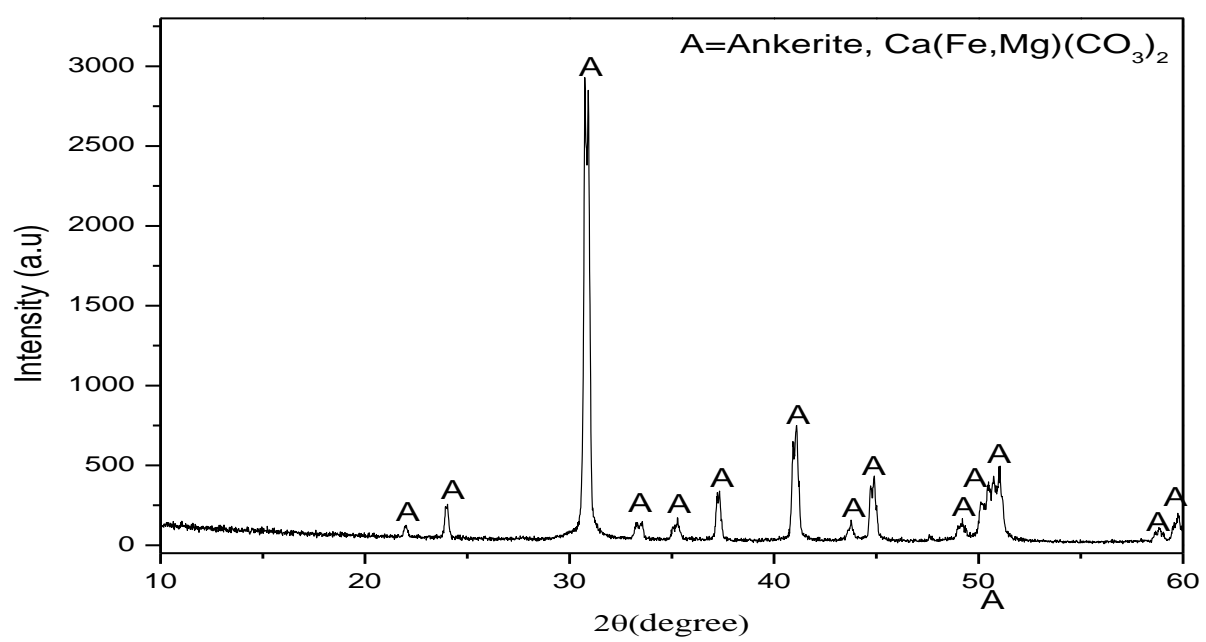

Figure 1. The XRD patterns of limestone from Ambunten, Sumenep

Figure 1 is the diffraction patterns of limestone from Ambunten Sumenep before calcination. The result of qualitative analysis based on search and match result of dominant phase on limestone is ankerite $\left(\mathrm{Ca}[\mathrm{Fe}, \mathrm{Mg}]\left[\mathrm{CO}_{3}\right]_{2}\right)$ without impurity with reference JCPDS no. 00-041-0586 with a value of $2 \theta=$ $21.97^{\circ}, 24.00^{\circ}, 30.78^{\circ}, 33.30^{\circ}, 35.25^{\circ}$, $37.25^{\circ}, 41.00^{\circ}, 43.65^{\circ}, 44.85^{\circ}, 49.15^{\circ}$, $50.20^{\circ}, 50.70^{\circ}, 51.00^{\circ}, 58.88^{\circ}$, and $59.55^{\circ}$. Ankerite has a rhombohedral structure with a cell parameter $\mathrm{a}=$ 4.8312(2) $\AA$. and $\mathrm{c}=16.166$ (3) $\AA$ (Ross and Reeder, 1992). Polymorphs of ankerite are dolomite $\left(\mathrm{CaMg}\left[\mathrm{CO}_{3}\right]_{2}\right)$ and kutnohorite ( $\left.\mathrm{Ca}\left[\mathrm{Mn}, \mathrm{Mg}, \mathrm{Fe}^{2+}\right]\left[\mathrm{CO}_{3}\right]_{2}\right)$. 


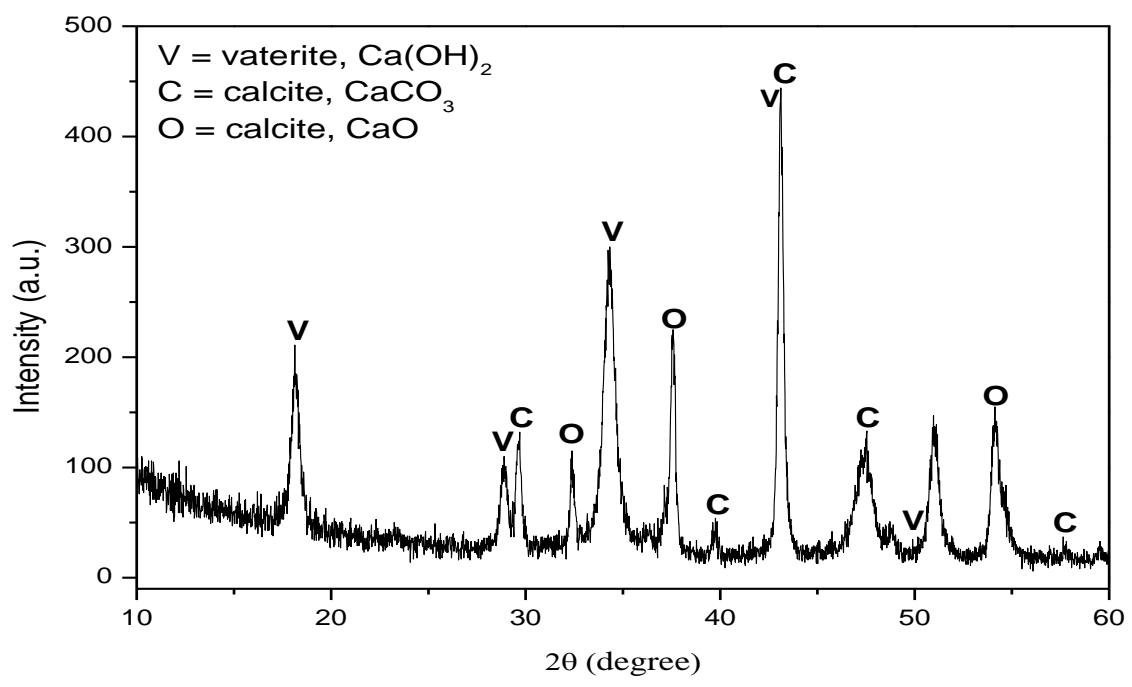

Figure 2. The XRD patterns of calcined limestone from Ambunten, Sumenep

Figure 2 is the diffraction patterns of limestone from Ambunten Sumenep after calcination. The result of qualitative analysis based on search and match result there are three phases which are identified that is vaterite $\left(\mathrm{Ca}[\mathrm{OH}]_{2}\right)$ with reference JCPDS no. 00-084-1266, calcite $(\mathrm{CaO})$ with reference JCPDS no. 00-077-2376 and calcite $\left(\mathrm{CaCO}_{3}\right)$ with reference JCPDS no.00-072-1937. Results of semiquantitative analysis with search and match can be seen in table 2 below:

Tabel 2. Analysis semiquantitative of calcined limestone

\begin{tabular}{ccc}
\hline Compound & $\begin{array}{c}\text { Amount } \\
(\%)\end{array}$ & $\begin{array}{c}\text { Crystal size } \\
(\mathrm{nm})\end{array}$ \\
\hline $\mathrm{Ca}[\mathrm{OH}]_{2}$ & 40.3 & 28.44 \\
$\mathrm{CaO}$ & 30.4 & 44.49 \\
$\mathrm{CaCO}_{3}$ & 29.3 & 32.47 \\
\hline
\end{tabular}

Based on qualitative and semiquantitative analysis (Table 2) it was seen that after calcination at $850^{\circ} \mathrm{C}$ for 6 hours of limestone with ankerite phase $\left(\mathrm{Ca}[\mathrm{Fe}, \mathrm{Mg}]\left[\mathrm{CO}_{3}\right]_{2}\right)$ decomposed to $\mathrm{Ca}[\mathrm{OH}]_{2}, \mathrm{CaO}$ and $\mathrm{CaCO}_{3}, \mathrm{Fe}$ and $\mathrm{Mg}$ oxides disappear. This is consistent with that done by Kök et al (2008) that the dolomite will decompose into all calcite at a temperature of $810-920^{\circ} \mathrm{C}$. When seen in the Table 2, the $\mathrm{CaO}$ formed only $30.4 \%$, this is because the formed $\mathrm{CaO}$ absorbs water vapor quickly (hydration) so that there is a $\mathrm{Ca}(\mathrm{OH})_{2}$ phase when tested with XRD (Liu et al, 2012; Suprapto et al, 2016). Note that calcination of limestone at $850^{\circ} \mathrm{C}$ is unlikely to have $\mathrm{Ca}(\mathrm{OH})_{2}$ phases.

The presence of a calcite $\mathrm{CaCO}_{3}$ phase indicates that $\mathrm{CaO}$ also reacts quickly when in contact with air (carbonation) when the calcination process is obtained (Liu et al, 2012; Suprapto et al, 2016). The $\mathrm{CaCO}_{3}$ phase is observed at $2 \theta 29.65^{\circ}, 39.67^{\circ}, 43.10^{\circ}$, $47.53^{\circ}, 48.82^{\circ}$ and $57.76^{\circ}$. As for the calcite $\mathrm{CaO}$ phase observed there are at 
three peaks which are at $2 \theta=32.37^{\circ}$, $37.58^{\circ}$, and $54.20^{\circ}$ according to the angle $2 \theta$ at JCPDS ie $32.2^{\circ}, 37.3^{\circ}$ and $58.3^{\circ}$ (Mohadi et al, 2013; Habibie et al, 2017; Suprapto et al., 2016, Zhu et al., 2011).

Based on the XRD analysis, the size of the $\mathrm{CaO}$ crystal formed can be calculated using the equation (1) of the Scherrer equation. The calculation results are presented in Table 2. The average $\mathrm{CaO}$ crystal size is $44.49 \mathrm{~nm}, \mathrm{Ca}(\mathrm{OH}) 2$ is $28.44 \mathrm{~nm}$ and $\mathrm{CaCO} 3$ is $32.47 \mathrm{~nm}$. Then the crystal size range is 28.44 $44.49 \mathrm{~nm}$. This measure is not much different from that done by Aqliliriana et al (2015) which is between $28-42 \mathrm{~nm}$.

FTIR measurements were performed in order to identify the functional groups of $\mathrm{CaO}$ present in a compound. FTIR analysis of calcined limestone was carried out at $300-4000$ $\mathrm{cm}^{-1}$ wavenumbers. Fig. 3 is a calculated limestone FTIR spectra. The $\mathrm{CaO}$ spectra were seen at $3641.24,1417.12$ and 874.14 $\mathrm{cm}^{-1}$. Peak $3641.24 \mathrm{~cm}^{-1}$ shows the presence of $\mathrm{OH}$ groups of $\mathrm{Ca}(\mathrm{OH})_{2}$ with sharp peak characteristics, possibly derived from $\mathrm{CaO}$ reactions with water molecules (hydration) (Mohadi et al, 2013; Suprapto et al, 2016). The 1417.12 $\mathrm{cm}^{-1}$ peak indicates the presence of asymmetrical and non-symmetrical O-C$\mathrm{O}$ stretch attached to the $\mathrm{CaO}$ surface. The peak of $874.14 \mathrm{~cm}^{-1}$ is also the peak of the carbonate group (Mohadi et al, 2013; Suprapto et al, 2016).

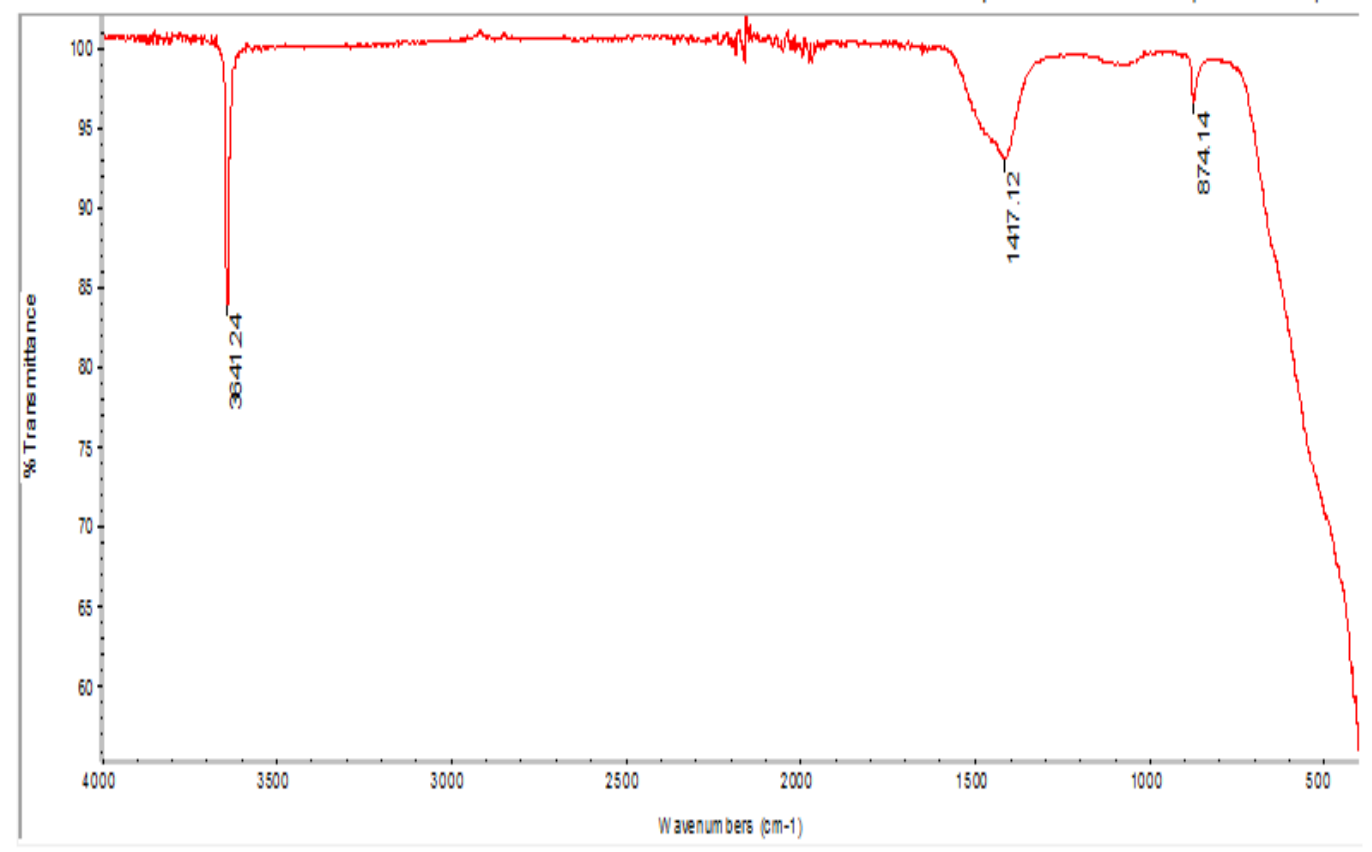

Figure 3. FT-IR spectra of calcined limestone from Ambunten, Sumenep 


\section{Conclusions and Suggestions}

Calcium oxide $(\mathrm{CaO})$ has been successfully synthesized from Ambunten Sumenep limestone by the calcination process. Characteristics of $\mathrm{CaO}$ synthesis results can be seen from the results of XRD test identified with $\mathrm{CaO}$ calcite phase rhombohedral structure. $\mathrm{CaO}$ crystal size between $28.44-44.49 \mathrm{~nm}$. While from the FTIR test results there is the absorption of wave numbers by carbonate groups in $3641.24,1417.12$ and $871.14 \mathrm{~cm}^{-1}$.

\section{Acknowledgments}

The authors would like to acknowledge the support for this work provided by Research cooperation between universities, DRPM, Ministry of Research, Technology and Higher Education (2017), Research Institutions and Community Service University of Trunojoyo Madura.

\section{References}

Aqliliriana, C. M., Ernee, N. M., and Irmawati, R. (2015). Preparation and Characterization of Modified Calcium Oxide From Natural Sources and Their Application in The Transesterification of Palm Oil. International Journal of Scientific and Technology Research. 4 (11), 168 -175.

Arifin, Z., Apriliani, N.F., Zainuri, M., and Darminto. (2017). Characterization of Precipitated $\mathrm{CaCO}_{3}$ Synthesized from Dolomite. IOP Conference Series: Material Science and Engineering. 196, 1-4.

Aziz, M. (2010). Batu Kapur dan Peningkatan Nilai Tambah serta
Spesifikasi untuk Industri. Jurnal Teknologi Mineral dan Batubara. 6 (3), 116-131.

Granados, M. L., Poves, M. D. Z., Alonso, D. M., Mariscal, R., Galisteo, F. C., Moreno-Tost, R., Santamar, J., Fierro, J. L.G. (2007). Biodiesel From Sunflower Oil By Using Activated Calcium Oxide, Applied Catalysis B: Environmental. 73, 317-326.

Habibie, S. Wargadipura, A. H. S., Gustiono, D., Herdianto, N., Riswoko, A., Nikmatin, S., and Clarke, S. (2017). Production and Characterization of Hydroxyapatite Bone Substitute Material Performed From Indonesian Limestone. International Journal of Biomedical Engineering and Science (IJBES). 4 (1), 11-23.

Itodo, A.U., Namonu, L.A., Ikape, V.O. (2017). Calcination Analysis, Characterization and Dyestuff Adsorption Potential of Nigerian Limestones. American Journal of Chemistry and Applications, 4(1), 620.

Khaira, K. (2011), Pengaruh Temperatur dan Waktu terhadap Karakteristik Precipitated Calcium Carbonate (PCC). Jurnal Saintek, 3 (1), 33-43.

Kök, M.V. and Smykatz-Kloss, W. (2008). Characterization, Correlation And Kinetics Of Dolomite Samples As Outlined By Thermal Methods. Journal of Thermal Analysis and Calorimetry, 91(2), 565-568.

Ljupković, R. B., Mićić, R. D., Tomić, M. D., Radulavić, N. S., Bojić, A. Lj. and Zarubica, A. R. (2014). The 
significance of the Structural Properties of $\mathrm{CaO}$ Catalyst in the Production of Biodiesel: An Effect of the reduction of Greenhouse Gas Emissions. Hem. Ind. 68 (4), 399412.

Mohadi, R., Lesbani, A., Susie, Y.(2013). Preparasi dan Karakterisasi Kalsium Oksida $(\mathrm{CaO})$ dari Tulang Ayam. Chemistry Progress. 6 (2), 76-80.

Ross, N. L. And Reeder, R. J. (1992). High Pressure Structural Study of Dolomite and Ankerite. American Mineralogist. 77, 412 - 421.

Sari, N., Jalil, Z., and Rahwanto, A.(2013). Identification of Oxide Compound in Dolomite Mineral from Aceh Tamiang Region. Journal of Aceh Physics Society, SS, 2 (1), 1-2.

Suprapto, Fauziah, T.R., Sangi, M.S., Oetami, T. P., Qoniah, I., Prasetyoko, D. (2016). Calcium Oxide from Limestone as Solid Base Catalyst in Transesterification of Reutealis trisperma Oil. Indonesian Journal Chemistry, 16 (2), 208-213.

Zhu, Y., Wu, S. and Wang, X. (2011). Nano $\mathrm{CaO}$ Grain Characteristics and Growth Model under Calcination. Chemical Engineering Journal, 175, 512-51 